\title{
Terra nullius, Inuit Habitation and Norse Occupation - With Special Emphasis on the 1933 East Greenland Case
}

\author{
Peter Thomas Ørebech^, \\ Professor of jurisprudence, Faculty of Biosciences, Fisheries and Economics, UiT - The \\ Arctic University of Norway, Tromsø, Norway
}

«Until 1925 no eskimo with the exception of the Angmagssalik population, stayed permanently in East-Greenland». ${ }^{1}$

\begin{abstract}
Sovereignty acquired by occupation entails "recognize[d] title based on discovery," "a reasonable period [of] ... effective occupation of the region claimed to be discovered" and "the continuous and peaceful display of State authority." Only terra nullius is subject to occupation. A territory inhabited by indigenous groups that sustain social and political organization may impede an occupying power because the terra nullius requirement fails. While sovereignty over thinly populated areas are often lax, case law requires less public involvement in these sparsely inhabited areas. This study reveals that the Dano-Norwegian Kings regarded the Inuit as "our subjects." The Kings' pretention of absolutum dominium and jurisdiction involved both the Norse and Inuit ethnic groups and "bygð ok ubygð" (settled and unsettled) land. The exodus of the Norse peoples in 1450 $\mathrm{AD}$ for 200 years did not undermine the acquired sovereignty of the Dano-Norwegian Crown, which as a result, spoiled the 1931 Norwegian pretentions to legally occupy East-Greenland. Denmark's triumph in the 1933-East Greenland case resulted from a "zero-sum principle." More than a 100 years earlier, the Danish Kingdom lost a succession of countries and dependencies. The 1814 Kiel Treaty transferred mainland Norway to Sweden, but explicitly states that none of the ancient Norwegian dependencies, Greenland, Iceland and Faroe Islands would follow suit. Thus, these territories remained part of the Kingdom of Denmark.
\end{abstract}

Keywords: discovery; occupation; sovereignty; Norse and Indigenous peoples; Inuits; Eastern Greenland Case - Permanent Court of International Fustice 1933

Received: January 2016; Accepted: April 2016; Published: May 2016

\section{Topic, problems for discussion and presentation}

This article examines whether historical occupation attempts have failed due to the presence of natives, by failing to qualify as terra nullius "territory belonging to no

^Correspondence to: Peter Thomas Ørebech UiT - The Arctic University of Norway (BFE), 9037 Tromsø, Norway. Email: peter.orebech@uit.no 
one." ${ }^{2}$ A second issue is to reveal the ratio decidendi of the 1933 East-Greenland Case. $^{3}$

The discussion considers two instances of occupation. Firstly, the Norse settlements in Greenland in the year 986 (Eirik Raude), ${ }^{4}$ and secondly, the 193132 Norwegian occupation of East Greenland. The link between these instances is as follows: If the original occupation included all of Greenland and this occupation is still holds, the latter endeavor is invalid.

If the mere presence of natives is enough, the analysis boils down to a study of facts. Did natives de facto inhabit the occupied land? As this article suggests, however, qualified habitation is required and includes maintaining "social and political organization." 5 This article also considers whether discontinuing state jurisdiction over or deserting a territory invalidate the once valid acquisition of sovereignty.

This article omits analysis of possible authentication requirements, i.e. physical installation versus symbolic tokens. ${ }^{6}$ "The turf and twig ceremony, or among the continental nations the erection of a cross or other marker, was evidently all that was needed for creating a right of sovereignty in legal fashion." 7 Since this article examines unilateral occupation, bilateral agreements with local rulers ${ }^{8}$ is outside the scope of the analysis. Thus, natives may accede to a union by renouncing their sovereignty.

Original texts are often self-explanatory, and clarifying comment is hardly necessary. In such cases, I prefer to let the original text speak for itself.

Chapter 2 examines Danish and Norwegian pretentions to occupy Greenland, with special focus on the 1933-Court decision. Chapter 3 deals with the role of Inuit habitation regarding the terra nullius principle and the subsequent ratio decidendi of the court. Chapter 4 is the conclusion.

\section{The East Greenland dispute: The positions of Denmark and Norway}

... no right of self-determination is recognized in international law where it clashes with the world system of state sovereignty. ${ }^{9}$

The Norwegian and Danish positions to the original Norse occupation of 986 AD and the Norwegian attempt at annexation of 1931-32 confirm that the two rivals have followed legal principles that claim that a de facto initiation and implementation of powers should accompany pretentions of dominium.

A 1924 -convention ${ }^{10}$ settled several of the Denmark-Norway discrepancies and guaranteed Norwegian fishing and hunting rights, without prejudice to sensitive jurisdictional issues. ${ }^{11}$ However, Norwegian pressure groups ensured that the convention failed, which resulted in the 1933-dispute before the Permanent Court of International Justice PCIJ.

\subsection{The Norwegian position of $1931-33^{12}$}

A domestic lobby orchestrated a private occupation that subsequently forced the Ministry of Foreign Affairs to declare (Royal Decree of 12 July 1932) Eirik Raudes 


\section{P. T. Ørebech}

Land (East-Greenland) - a territory void of Inuit habitation ${ }^{13}$ - as Norwegian territory.

The Norwegian Government's 1932 rejoinder clarified that the Norwegian position was - and has always been - that the Danish possessory pretentions to Greenland in its entirety, and hence including Eirik Raudes Land, were without factual and legal support. The obvious conclusion was that Eirik Raudes Land was terra nullius in 1814. Norwegian documents from negotiations and dispute settlements with Denmark regarding East Greenland ${ }^{14}$ did not consider the role of natives in relation to the terra nullius justification because there were no Inuit villages located in East Greenland at the time. To circumvent Inuit habitation and justify occupation, Norway had adjusted the borders of the occupied area, declaring that the "rest of the coast [beyond latitude $73^{\circ} \mathrm{N}$ ] and the interior of East Greenland has always been considered terra nullius." 15 The "Norwegian Government [...] found it imperative to occupy the territory in East Greenland which, on account of Norwegian economic interests there, ought naturally to be under Norwegian jurisdiction."16 Finally, Norway stated that the "East Greenland Treaty of 1924 is not affected by the occupation." ${ }^{17}$ However, this position gained little support (Section 3).

The key question was whether Norsemen (before 1450 AD) had occupied all of Greenland, and that no subsequent changes had been made to this original status. ${ }^{18}$ Norway objected to such an idea: the Danish claim that "sovereignty over Greenland in its entirety has been upheld for hundreds of years"19 cannot escape the astonishment of whoever is informed "of the Danish diplomatic action that took place during the years 1916 to $1921 . " 20$ Norway brought attention to the inconsistent reasoning in Denmark's communication with the international societies of states. "[T] he attitude [...] was inconsistent with a claim to be already in possession of the sovereignty over all Greenland, and that in the circumstances she is now stopped from alleging a long established sovereignty over the whole country." ${ }^{21}$ In defense of Denmark, it should be pointed out that the Danish claim for multilateral support does not necessarily prove that it had sovereignty over Greenland before $1916^{22}$ Clearly, apprehension of international law is just that, an apprehension. The international society of states' consent is needed to establish a viable legal opinion.

Norway claimed that the Norse occupation of 986 AD was limited: "It was only the two settlements in West Greenland that came under Norwegian sovereignty with the Greenlander's 1261-submission under the Norwegian King."23 Norway concluded that areas in the northern part of West-Greenland and parts of EastGreenland beyond Inuit habitation were never part of the Norwegian kingdom. Norway also claimed that the Inuit peoples failed to qualify as the King's subjects, due to their paganism. The mission to convert the Inuit from paganism, which was banned in territories of Norway, failed. ${ }^{24}$ This position is disputed (Section 3).

Norway admitted that its delimitation of the East-Greenland occupied territory carefully avoided including native settlements. The original area of occupation, which included areas north of latitude $71^{\circ} 30^{\prime},{ }^{25}$ was redefined to circumvent east coast Inuit habitation. 
Apparently, Norway departed even further from the 1919 Ihlen-Declaration (see Chapter 2.4). A communication from the Norwegian Foreign office on 17 August 1921 makes it clear that Norway did not recognized Danish sovereignty over all of Greenland. ${ }^{26}$

\subsection{The Danish position in the 1920s}

Denmark claimed that the Norwegian position on East-Greenland occupation was contradictory. Denmark argued that Norway was claiming her historic right to Greenland as including "the whole of Greenland, hereunder the de facto non-settled East Greenland." 27 However, Norway rejected this position when the Danes put it forward.

The Inuit's need for protection against foreign exploitation and the dissemination of disease ${ }^{28}$ shaped Danish politics. ${ }^{29}$ This argument is however inconsistent with the Danish view that the Inuit were conquistadors fighting the Norse settlements. ${ }^{30}$ However, assimilation theories promoted by two famous Norwegians; missionary Hans Egede (1686-1758) and the Nobel Peace Prize Laureate Fridtjof Nansen (1861-1930), ${ }^{31}$ make this combat-scenario unlikely.

Denmark wanted to protect the Inuit whose trade allegedly would suffer irreparable damage from Norwegian exploitation. "On 1 April 1925, the Danish Government promulgated a law" "on fishing and hunting in Greenland waters," etc.; followed on 18 April by a law "concerning the administration of Greenland." The former law - which served as the basis for a 22 May 1925 Proclamation ("Notice to Mariners"), by the Greenland Directorate "on navigation in the seas around Greenland" - reserved harvesting in its waters for Danish subjects settled in Greenland exclusively, and for "persons obtaining special licenses." 32 Whether this was a real conflict of interests may be disputed since Inuit hunters are only infrequently referred to as suppliers of fish, seal-products, furs etc. (judgment p. 32), or as subjects of the King of Denmark-Norway (p. 28, 37, 39). Since Norwegian fishing took place on the East coast, where there were no Inuit, Norway could easily have argued that Denmark had fabricated this threat.

Denmark declared sovereignty over all of Greenland. ${ }^{33}$ Accordingly, the Norwegian 1931-annexation of East-Greenland imperiled Danish territorial integrity. Seen as part of the greater picture, this illustrates the conflict between "declarations of independence" and "self-determination, particularly where it involves any measure of international personality, [which] is thought to violate territorial integrity." 34

Denmark claimed that Norway had tacitly recognized the Danish claim over all of Greenland. ${ }^{35}$ Denmark advanced that Ihlen Declaration (Section 2.4) "debarred Norway from proceeding with any occupation of territory in Greenland." 36 Denmark also found additional support in several "other acts recognized an existing Danish sovereignty there." 37

\subsection{Icelandic researcher's perspective}

Greenland societies were under the Kings Rules, the Icelandic laws (i.e. “Grágás”) as well as justifications by the Iceland Althing. The Norse immigration to Greenland 


\section{P. T. Ørebech}

i.e. Eirik Raude and his companions, signifies the second decisive element of PCIJ to the extensive reach of the original occupation. Both "Vestribygda" and "Austribygda" were located in West-Greenland. While Norse people in ancient times occasionally hunted and fished at East-Greenland north of Scoresbysund, ${ }^{38}$ their homesteads were all located in the west. The "Landnám" (occupation) included both "bygð ok ubygð" (settled and unsettled) land.

The absolute monarchy of the King of Denmark-Norway was established in 1661 AD. The centralized power in Copenhagen was, however, not the one and only authority that Greenlanders were expected to obey:

When a group of Icelandic citizens [...] colonized the land and instituted an Icelandic court system, Greenland came under the jurisdiction of "vár lög" [our law] accordingly, no different from the main part of Iceland. This includes not only the Greenland settlements, but all of Greenland in the same way that both settled and unsettled land in Iceland belonged to the Icelandic law society. ${ }^{39}$

Dúason establishes attainment of the sovereignty criteria in the following way: Norse people populated Greenland. Subsequently, Inuit settled in Western-Greenland. Greenlanders submitted to the Norwegian King in 1261 (called "sóttmáli"). The execution of sovereign power become apparent by both Dano-Norwegian and Icelandic jurisdiction and rule. Consequently, the King's pretention of dominium is consistent with the de facto executive power exercised over Greenland.

The 1933-court case took no notice of whether settlers were Icelandic, Norwegian or Danish. Exploration took place along all shores except the north coast, which was ice-covered all year around. The territory was clearly defined as "all of Greenland" and had administrative-, dispute settlement and enforcement systems. ${ }^{40}$

Dúason dismissed the idea that Inuit habitation limited Icelandic colonization of Greenland. Icelanders and Inuits alike were all subject to Iceland legislation and the Althing. Dúason's position was that Dano-Norwegian sovereignty developed over a prolonged period. He also argued that Inuit intrusion did not disrupt the original sovereignty because of the late arrival of the Inuit population and the fact that they did not establish competing societies. To the contrary, the presence of the Inuit contributed to maintaining the sovereignty of Denmark-Norway during the late Middle Ages.

\subsection{Other theories: the Ihlen declaration of 1919}

On the surface, it seems as if differences in the justification of the Ihlen declaration were decisive. However, the special position taken by the majority would have been impossible if it had not been for the peculiar theory on the prerequisites to procure sovereignty to no man's land. ${ }^{41}$

Social scientists point to the Norwegian Minister of Foreign Affairs Nils Ihlen's declaration as the reason for the Norwegian failure at the PCIJ in 1933. An alternative hypothesis is that the existence of the Inuit had little influence upon the 1933-court decision. Social scientists frequently claim that Norway's misfortune in Eastern 
Greenland $(1931)^{42}$ was caused by Ihlen's declaration on 22 July $1919 .{ }^{43}$ A common position is that "the Ihlen declaration, plus the inactivity of Norway until the 1920's ... coupled with continual Danish diplomatic offensives, resulted in [Danish] final victory." 44 Thus, this position does not blame the Norwegian fiasco on the indigenous peoples' presence, i.e. the Danish argument that the Inuit needed protection against the exploitative Norwegian hunters and fishermen (Section 2.2).

The Ihlen text reads, "that the plans of the Royal [Danish] Government with regard to Danish sovereignty over the whole of Greenland will not encounter any difficulties on the part of Norway." 45 A Norwegian historian states, "[t]he Ihlen declaration became one of the decisive points ... The Ihlen declaration by itself was, according to the court's justification, sufficient to deprive Norway of a right to occupy parts of East Greenland." 46 Without this mistake, ${ }^{47}$ others would have predicted a different ruling by the court: The Ihlen declaration ... was a communication error without which the ruling would have resulted in another specification and interpretation ... and result. ${ }^{48}$ This regrettable result did not result from the actionist policy that led to the occupation. "The occupation was a criticized failure ... both due to the Norwegian theory on the East-Greenland as terra nullius ... but also due to the mistaken claim that the Ihlen declaration was non-binding." 49 Thus, the Norwegian position was wrong in at least two ways.

Foreign scholars followed this line of thought, c.f. "the ill-advised Ihlen declaration in which the Norwegian foreign minister had tacitly recognized the Danish position. Even though clearly acting beyond the scope of authority, his remark proved to be one of the most costly in modern history." 50

I maintain that the declaration's role and impact has been misjudged, and subscribe to Dr. Ræstad's position:

At face value it seems like it was the differences in interpretations of the Ihlen declaration which was the crucial element; however in real life the majority's justification found little support in this declaration if it had not been for the ties to a special theory launched on the prerequisites of sovereignty acquisition. ${ }^{51}$

The theory in question claims, "it is Norway's responsibility to prove that the word 'Greenland' in these agreements is used in some special sense which does not include the uncolonized part of the East coast, and it is the opinion of the Court Norway that this has not been proven." 52

Evidently, the Ihlen declaration was not part of the court's ratio decidendi, it is obiter dicta no more, no less (see Section 3). "This finding [Danish sovereignty over Greenland in toto] constitutes by itself sufficient reason for holding that the occupation of 10 July 1931, and any steps taken in this connection by the Norwegian Government, were illegal and invalid." ${ }^{, 53}$ I thus subscribe to the position that the PCIJ "announced conclusions revealing deference for the value of ancient claims as the foundation of rights of sovereignty over an unpossessed and unexplored territory." 54 Whether this decision is "outdated litigation, rendered inoperative by later decisions," is outside the scope here. ${ }^{55}$ 


\section{P. T. Ørebech}

This declaration by M. Ihlen has been relied on by the Counsel for Denmark as a recognition of existing Danish sovereignty in Greenland. The Court is unable to accept this point of view. A careful examination of the words used and of the circumstances in which they were used, as well as subsequent developments, shows that $M$. Ihlen cannot have meant to be giving then and there a definitive recognition of Danish sovereignty over Greenland, and also shows that he cannot have been understood by the Danish Government at the time as having done so. ${ }^{56}$

The court found that the importance of the Ihlen declaration was that it "constitute[d] an engagement obliging Norway to refrain from occupying any part of Greenland." 57

What the Court cannot regard as being in accordance with the undertaking of 22 July 1919, is the endeavour to replace an unconditional and definitive undertaking by one which was subject to reservations: and what it is even more difficult for the Court to admit is that, notwithstanding the undertaking of 22 July 1919 , by which she promised to refrain from making difficulties in the settlement of the Greenland question, Norway should have stipulated that "Eastern Greenland must be Norwegian." 58

Thus, the Ihlen declaration was not a key element in the PCIJ's ruling in favor of Denmark's claim of possessing the whole of Greenland. Instead, PCIJ found that Norway according to the Ihlen text undertook not to occupy areas of Greenland, habited as well as uninhabited. ${ }^{59}$

\section{The Norse- and Inuit settlements: Basis for- and limits to occupation}

Natives could not give up some rights in order to obtain others because they are all too important to be bargained away. The [Indian tribe of] Crees insisted that the right of self-determination is an inherent right of all peoples, and that the declaration must state this right clearly and unequivocally. ${ }^{60}$

\subsection{The status of the Greenland Inuit}

Before turning to a discussion of the law, let us consider the factual situation. When the Norsemen arrived at "Eystrabygði" and "Vestrabygði" (986 AD) there was no Inuit population in the area. The Baffin Island Inuit first arrived in 900-1100. ${ }^{61}$ Thus, the indigenous presence that impedes occupation ${ }^{62}$ is irrelevant in this case. According to Icelandic law and international customary law, ${ }^{63}$ the Icelanders took possession of the discovered land. With the subsequent colonization and establishment of the Iceland system of legal assembly (Althing), Greenland became an incorporated part of the Iceland's jurisdiction. ${ }^{64}$

An expedition of Norse settlers northwest of Greenland in 1266 discovered former Inuit settlements along the shores of Baffin Island. Returning to West-Greenland, the explorers found settlements there as well. However, permanent settlements were not found until they explored the southwest coast of Greenland at "Upernivik-district" (at $\left.70^{\circ} \mathrm{N}\right) .{ }^{65}$ 
While Norse settlement was located in the southwest, the Inuit population was scattered across a couple of areas on the west coast of Greenland. On the east coast, there was no permanent habitation. There were no Inuit inhabiting the area of East-Greenland occupied by Norway on 10 July 1931. A head of an English expedition observed on the east coast in 1823, a small Inuit group consisting of 12 people was observed by an English expedition on Greenland's east coast in 1823 . A German North-pole expedition also observed a few natives, but all the Inuit previously living north of Scoresby [Ittoqqortoormiit, at $70^{\circ} 29^{\prime} 8$,] had perished, most likely from famine. The explorers found skeletons of families in the ruins of houses. ${ }^{66}$ In 1925, Denmark settled Inuits, 70 adults and children, in the area. ${ }^{67}$

The validity of the Norwegian 1931-occupation required, either that the ancient Norse settlements ceased to exist or that its territorial reach never included the Eastern part of Greenland. The downfall of Norse civilization at the end of the fourteen hundreds might have precipitated such an event. What happened to the Norsemen?

The word "conquest" is not an appropriate phrase [...] The principle does not apply in a case where a settlement has been established in a distant country and its inhabitants are massacred by the aboriginal population. Nor is the fact of "conquest" established. It is known that the settlements disappeared at an early date, but at the time there seems to have been a belief that despite the loss of contact and the loss of knowledge of the whereabouts of the settlements one or both of them would again be discovered and found to contain the descendants of the early settlers. ${ }^{68}$

Regardless of the ancient situation, the non-existence of settlements at the time of the PCIJ deliberations was a fact: "Until 1925 no Inuit group, with the exception of the Angmagssalik population, stayed permanently in East-Greenland." 69 Since this population was located south of the area claimed by Norway, Eirik Raudes Land, no groups of natives threatened the Norwegian terra nullius position.

\subsection{The scope of terra nullius as applied by the 1933-East-Greenland Court}

The focus of this section is to apply the concept of terra nullius to the Greenland case. Of special interest is the territorial reach of the occupation - the jurisdictione ratione terrae - as it applies to Inuit settlements in Greenland.

\subsubsection{The terra nullius concept}

A basic question is whether the presence of natives played a role in maintaining Dano-Norwegian authority over Greenland, and if so, whether a minimum population density is required to prevent annexation attempts. The key issue is whether the original occupation included the whole of Greenland. If so, the question is whether the approximately 200 years of lost contact between the Dano-Norwegian Kingdom and the Greenland's remaining inhabitants qualifies as dereliction of land. If so, the coming of modern age convened by the Hans Egede 1721-arrival in Nuuk, was a successful resurrection of this ancient occupation. 


\section{P. T. Ørebech}

If two states are competing to gain sovereignty over a territory, determining the rightful party should follow the principle of the "relative strength of the titles."70 The relevant criteria points at actual enforcement as the superior factor. Established authority "attested also by external signs of sovereignty, had already reached such a degree of development, that the importance of maintaining this state of things ought to be considered as prevailing over a claim possibly based either on discovery in very distant times and unsupported by occupation, or on mere geographical position."71 Such "an inchoate title could not prevail over the continuous and peaceful display of authority by another State; for such display may prevail even over a prior, definitive title put forward by another State."72 While the Dano-Norwegian conflict could arguably be seen as two-states colliding with concurrent occupation, this is not the case, because of the approximately 1000-year interval between the Norse settlement in $986 \mathrm{AD}$ and the Norwegian East-Greenland Declaration. I thus do not consider the situation of two-states competing a relevant argument for the purposes of this article.

\subsubsection{Recognition of the international society of states}

A country's presumption of sovereignty may turn out differently in cases where sovereignty pretensions meet objections. ${ }^{73}$ The international society of states was supportive of the alleged Danish sovereignty. The court found that "foreign countries appear to have acquiesced in the claims of the King of Denmark" of continuous sovereignty over Greenland. ${ }^{74}$ Concomitantly the court stated, "one of the peculiar features of the present case is that up to 1931 there was no claim by any Power other than Denmark to the sovereignty over Greenland. Indeed, up till 1921, no Power disputed the Danish claim to sovereignty."75

United Nations Charter Article 73 regulates tribal societies that are not full-blown national states, as stated in the 1960 Declaration on the Granting of Independence to Colonial Countries and Peoples: "sacred trust, the obligation to promote to the utmost [...] their political, economic, social, and educational advancement." For other areas "State practice of the relevant period indicates that territories inhabited by tribes or peoples having a social and political organization were not regarded as terra nullius."76 Accordingly, national states that are not yet fully developed enjoy legal protection against occupation, and accordingly, cannot classify as terra nullius.

\subsubsection{Thinly populated countries}

The classification of sparsely inhabited, non-governed territories is more intricate. How do we determine what is terra nullius? At least two views come forward. First; "Roman law was more resource [arsenal for logic] than road map [directive] ... Rather than applying a portable doctrine, direct and indirect references to discovery, possession, res nullius and terra nullius fit within a methodology of legal analogy and recommended a set of weakly defined practices for acquiring sovereignty.",77 Secondly, while ancient traditions required nothing but an act of "discovery with symbolic taking of possession" as adequate means "to constitute legal title to terra nullius," later practices show that "[o]ccupation has remained a concomitant test of 
legal title to terra nullius" which, however, requires a "less rigid test ... than in a heavily settled area."78 This "relativism principle" applies to the Greenland case.

My guess is that "minimum requirement to sustain territorial claims in the Polar Regions is likely to be less than in more hospitable and accessible places; yet, the grounds sustaining the judgment in this [Greenland] case clearly affirm that state activity is of the greatest importance, but that this activity may take forms other than a real or physical occupation."79

Valid occupation provokes lex temporae and -terrae issues. "[A]s from the tenth to the sixteenth centuries, if thinly populated or unsettled territory are considered, a less rigid test would be required to establish legal title to terra nullius than would be necessary were such acts attempted in a more recent period and in a heavily settled area." 80 The PCIJ verify this legal paradigm: "This special position can only have been derived from the sovereign rights which accrued to the King of Norway from the submission made to him by the early Nordic settlers and which descended to the Danish-Norwegian kings." 81 The Court underlined that the non-codified principles of sovereignty are case law based. This court found it

impossible to read the records of the decisions in cases as to territorial sovereignty without observing that in many cases the tribunal has been satisfied with very little in the way of the actual exercise of sovereign rights, provided that the other State could not make out a superior claim. This is particularly true in the case of claims to sovereignty over areas in thinly populated or unsettled countries. ${ }^{82}$

Clearly, Greenland qualifies as such a low-density territory.

\subsubsection{Well-organized native societies}

The discussion below focuses on whether a native society may impede colonial powers from occupying a stateless territory. Despite a seemingly valid occupation, a nation state's pretentions will fail if there is a well-functioning native society present in the area, as put forth in the 1933 Montevideo Convention on the rights and obligations of states. Discovery alone is insufficient to "create definitive title of sovereignty." ${ }^{83}$ Lawful, unilateral occupation resulting in sovereignty should satisfy other conditions as well, including these strictum jus prerequisites: 1) a "recognize[d] title based on discovery"; 2) "a reasonable period by the effective occupation of the region claimed to be discovered"; 84 and 3) "the continuous and peaceful display of State authority." 85

If the criteria of 1933 Montevideo Convention on the rights and obligations of states are satisfied, a colonial state cannot occupy a territory if a native people might, had it been an option - by a declaration of independence - have succeeded in establishing a nation state of their own.

UN-practice gives momentum to the validity of the Montevideo criteria; 1) a defined territory; 2) distinct population; 3) a government with substantial control over the population and territory; and 4) the capacity to engage in foreign relations: In the case of the Compact of Free Association between Palau and the United States, the UN recognizes "the authority of the Micronesian States with all four criteria 


\section{P. T. Ørebech}

normally cited for statehood. [...] In that regard, the compacts provided that the freely associated States would have full authority over foreign affairs except in relation to international defence and security." ${ }^{86}$ At its 3455th meeting, the Security Council voted unanimously to terminate the Trustship Agreement with respect to Palau, ${ }^{87}$ which means that Palau has "emerged into full nationhood." 88 Thus, the UN recognized that the fourth criteria of foreign affairs power was satisfied despite limitation on defense and security policy.

The Montevideo Convention text is the "best known formulation of the basic criteria for statehood." 89 This is also the U.S. position: "Under international law, a state is an entity that has a defined territory and a permanent population, under the control of its own government". ${ }^{90}$ Legal scholars acknowledge that the Montevideotext does reflect customary international law, ${ }^{91}$ and that the "Restatement follows the widely accepted definition set forth in the Montevideo Convention."92 As indicated, the United Nations and the International Court of Justice seem confident that these criteria are valid de lege lata.

Even though the criteria of statehood are widely accepted, some scholars have warned that the Montevideo Convention criteria are "no more than a basis for further investigation." "93 for investigation and debate, in particular the balance between "declaration of independence" and the often-absolute barrier of "territorial integrity." These issues are outside of the scope of this article.

The Inuit, who are unusually organized into well-functioning societies, ${ }^{94}$ may be a likely candidate for statehood. However, even if societies fail to satisfy the four criteria, the characteristics of terra nullius is inappropriate.

\subsubsection{Effective jurisdiction}

The occupation of Greenland, in accordance with Icelandic law and international customary law, ${ }^{95}$ protected the first settlers, both on settled and unsettled land. Not only the settlements - but also the entire Greenland (norðrseta) fell under Icelandic jurisdiction. ${ }^{96}$

Subsequent to discovery and occupation, effective jurisdiction is required. ${ }^{97}$ The efficiency requirement is measured by the factual implementation of power:

[I] $n$ the exercise of territorial sovereignty there are necessarily gaps, intermittence in time and discontinuity in space. This phenomenon will be particularly noticeable in the case of colonial territories, partly uninhabited or as yet partly unsubdued. The fact that a State cannot prove display of sovereignty as regards such a portion of territory cannot forthwith be interpreted as showing that sovereignty is nonexistent. Clearly valid occupation may take place despite the area being inhabited. Each case must be appreciated in accordance with the particular circumstances. ${ }^{98}$

Thus, the classification of territories results from discretionary decisions that ultimately belong to the International Court of Justice (ICJ). I subscribe to the position that the "manifestations of sovereignty over a small and distant island, inhabited only by natives, cannot be expected to be frequent, it is not necessary that 
the display of sovereignty should go back to a very far distant period." 99 From this, we may draw the conclusion that a "clandestine exercise of State authority over an inhabited territory during a considerable length of time would seem to be impossible," 100 as a basis for valid annexation.

Other visible instruments of jurisdiction include: legislation, surveillance and enforcement and dispute settlements. This is also confirmed by case law: "[I]n many cases the tribunal has been satisfied with very little in the way of the actual exercise of sovereign rights, provided that the other State could not make out a superior claim. This is particularly true in the case of claims to sovereignty over areas in thinly populated or unsettled countries." 101

The relatively lax Dano-Norwegian jurisdictions in ancient Greenland suits this pattern. In modern times, Denmark overruled Norway with regard to East-Greenland.

Successful annexation also requires jurisdictional "continuity." As confirmed by the Palmas Island case; it "suffice[s] to establish a continuous display of State authority over the island,"102 "[a]lthough continuous in principle, sovereignty cannot be exercised in fact at every moment on every point of a territory. The intermittence and discontinuity compatible with the maintenance of the right necessarily differ according as inhabited or uninhabited regions are involved."103 Occupation based on a single discovery is not sufficient. The same applies to a repeat discovery. An ad hoc and abrupt occupation does not qualify: "[I]t must [...] be shown that the territorial sovereignty has continued to exist and did exist at the moment which for the decision of the dispute must be considered as critical."104

A physical presence, even if it is long running, is insufficient. The triumphant sovereignty-claim requires legal efficiency: "[T]hat is, offer certain guarantees to other States and their nationals. International law does not recognize "reserved [...] exclusive influence of one State, in virtue solely of a title of acquisition which is no longer recognized by existing law, even if such a title ever conferred territorial sovereignty." 105 The jurisdiction claim obligates an in spe sovereign to establish a de facto presence within a reasonable time. A sovereignty claim goes hand in hand with a condition of "an inchoate title of discovery [that] must be completed within a reasonable period by the effective occupation of the region claimed to be discovered." 106 I subscribe to this legal platform.

\subsubsection{Tacitly abandoned jurisdiction}

A key question is whether an original discovery and valid occupation becomes derelict due to lax and inefficient presence and jurisdiction, i.e. the discussion whether "the absence of effective occupation of the uncolonized parts exposed the territory to the risk of permanent occupation by some foreign State."107 The Norse population disappeared for a period of 200 years. This interregnum "did not put an end to the King's pretensions to the sovereignty over Greenland."108 Seemingly, temporal absence of Norse inhabitants was unimportant because the Regent (1605) did not distinguish between Norse and Inuits since also the latter group qualified as "our subjects."109 


\section{P. T. Ørebech}

A previously gained title to territorial sovereignty does not necessarily vanish under vacation of property, rural depopulation, or other lack of human habitation. As stated in the 1933-case; "the disappearance of the Nordic Colonies did not put an end to the King's pretensions to the sovereignty over Greenland."110 On the other hand, a lack of jurisdiction - initiation and implementation or surveillance - may ruin a strong pretention of dominium. "[I]f for a prolonged span of time a potential claimant to territory in polar regions remains relatively inactive with respect to the demonstration of an animus occupandi, a title once regarded as sufficient to meet the requirements of law is dissipated by inactivity and the afflux of time." 111 This is conceivable and relevant for the Greenland case (see Section 3.3).

The 1933-case confirms that "a fine should be payable to the King whether the dead man was a Norwegian or a Greenlander and whether killed in the settlements or in the districts to which people went for the summer even as far North as under the Pole Star." 112 Since Inuit settled permanently throughout the centuries, the continuing presence of these people prevents the argument of territorial dereliction from gaining international acknowledgment.

Furthermore, the Kingdom of Denmark-Norway regarded natives living in Greenland as citizens: "Some Eskimos brought back [to Copenhagen] from Greenland in 1605 are described by the King as 'our subjects'. In 1635, in a letter addressed to the King of France, Danish-Norwegian King Christian IV describes Greenland and the natives as 'a divis nostris antecessoribus Regibus Norvegi ad Nos devoluta', ${ }^{113}$ respectively." 114

It is recognize that the Inuit population since long settled in Greenland and that by the mid-16th hundred King Christian IV regarded the Inuit as the "devoted subjects" of his Kingdom of Norway. Thus, the Ministries of Denmark-Norway did not distinguish between Norse and Inuit inhabitants of Greenland. This is the conclusion of Dúason. ${ }^{115}$ No Greenland constitution existed and Iceland notified people living in Greenland as citizens or peoples under Iceland law. Codex Grágás Chapter II (338-341), refers to any person in Greenland - whether Norse or Inuit as a "foreigner." 116

Does valid sovereignty require that a territory be permanently settled? In casu was the exercise of Danish control over some portions of Greenland sufficient to support its claim to exclusive sovereignty over the entire landmass? Could one possibly say that due to the fact that "[a] partir de cette époque, les Esquimaux furent pendant deux siécles les seuls maitres du pays," i.e. that 200 years before Hans Egede's arrival, Greenland was nothing but "terra nullius?",117

\subsubsection{Summing up}

The presence of natives is crucial: Cf. the United Nations Charter Article $73^{118} \mathrm{cf}$. General Assembly resolution 1514 (XV) of 14 December 1960, Declaration on the Granting of Independence to Colonial Countries and Peoples: "Immediate steps shall be taken, in [...] territories which have not yet attained independence, to transfer all powers to the peoples of those territories [...] in accordance with their 
freely expressed will and desire, without any distinction as to race, creed or colour, in order to enable them to enjoy complete independence and freedom" (paragraph 5). The accomplishment as proposed inter alia in the General Assembly resolution 2229 (XXI) Question on IFNI (liberalization movement) and Spanish Sahara should follow the "procedures for the transfer of powers in accordance with the provisions of General Assembly resolution 1514 (XV)" (paragraph 3). According to the reasoning in the IFNI case, the Inuits qualify as an indigenous people based on their settlement of Greenland a few decades after the Norse influx.

Concluding on the issue of geographical reach of the Danish annexation, "the Court is satisfied that Denmark has succeeded in establishing her contention that at the critical date, namely, July 10th 1931, she possessed a valid title to the sovereignty over all Greenland."119

\subsection{The 1933-court's line of reasoning: residual dominium and "zero-sum principle"}

As shown in the previous section, case law interpreted the terra nullius criteria with a special emphasis on the territorial reach of Danish sovereignty over Greenland. The aim of this section is to sort out the key issues that made the PCIJ subscribe to the Danish line of argument.

The 1933-court introduces the 1928 Palmas Island decision of the Permanent Court of Arbitration (award paragraph I), ${ }^{120}$ raising the issue of Dutch - in conflict with the US - sovereignty to this island. The court found that the valid title of The Netherlands was "founded on the peaceful and continuous display of State authority over the island."121 The key point was "whether or not the Netherlands have displayed sovereignty over the Island of Palmas (or Miangas) in an effective, continuous and peaceful manner at a period at which such exercise may have excluded the acquisition of sovereignty, or a title to such acquisition, by the United States of America." 122

Whether the natives of Miangas enjoyed the right to independence was not part of the Arbitrational Award because the natives - by their Regent - agreed on colonial rule. Thus, it was either Dutch- or US sovereignty. The setting is similar to the Denmark-Norway dispute over East-Greenland. A third solution, independence for the natives, was a non-option in 1933.

The 1380 union between Denmark and Norway is the PCIJ platform. ${ }^{123}$ This resulted in the "centralization at Copenhagen of the administration of the various countries which were under the sovereignty of the Dano-Norwegian Crown." 124 The Kingdom of Norway brought into the double-monarchy dependencies like the Hebrides, Orkneys, Shetland, Faroe Islands, Iceland and Greenland. PCIJ's reasoning follows a residual dominium and "zero-sum" principle. After the early period of unification (1380 AD) the Dano-Norwegian Kingdom deteriorated and in turn lost regions like Skåne, Båhuslen, Jämtland, Herjedalen, SchleswigHolstein and eventually all of Norway. The Kingdom of Denmark retained a few dependencies. 


\section{P. T. Ørebech}

The second element in the court's "red thread" is that "foreign countries appear to have acquiesced in the claims of the King of Denmark."125 Thus, the international society of states recognized Danish pretentions to Greenland.

The third argument is that " $[\mathrm{t}]$ hough at this time no colonies or settlements existed in Greenland, contact with it was not entirely lost, because the waters surrounding it [...] were regularly visited by whalers, and the maps of the period show that the existence and the general configuration of Greenland [...] were by no means unknown." "126 It was further stated that the King - by his "sovereignty, absolutum dominium and hereditary"127 - granted a trade monopoly to a specific Danish company. No competing state authority conducted any form of jurisdiction in the territory.

Due to Danish-Norwegian defeats during the Napoleonic Wars, Sweden - one of the victors - compelled Denmark to sign the 1814 Kiel Peace Treaty, which transferred Norway to Sweden. Denmark retained a few dependencies, i.e. islands that in ancient times used to be part of the realm of Norway. During the period when the Danish kings acquired sovereignty over Greenland after the termination of the Union between Denmark and Norway (1814 to 1819), Norway did not dispute Danish sovereignty over Greenland. In the words of the court, "In the early part of this judgment, it was recalled that when the King of Denmark was obliged to renounce, in favour of the King of Sweden, his kingdom of Norway, Article 4 of the Treaty of Kiel of January 14th, 1814, with the exception of renunciation Greenland, the Faroe Islands and Iceland." 128

In the aftermath of the signing of the Kiel Treaty, the Norwegians formally claimed "the restitution of the Faroes, Iceland and Greenland as being possessions which had formerly belonged to the Kingdom of Norway." 129 However, Danish refusal resulted in the Norwegian withdrawal of this request. Sweden later confirmed its position on behalf of Norway in a letter to the British Minister at Stockholm. ${ }^{130}$

This formal reasoning underlies the court's interpretation and application of law. The court's position was that in 1380 Norway entered into a personal union with Denmark under one regent by marriage, i.e. Queen Margrethe. The court found that "there is nothing to show that during this period Greenland, in so far as it constituted a dependency of the Crown should not be regarded as a Norwegian possession." 131 Subsequent practice confirms this Swedish-Norwegian position. The court refers to several international law instruments, ${ }^{132}$ and concludes that Norway's position subsequent to the Kiel Treaty de facto and de jure acknowledged Greenland (with Iceland and Faroe Islands) as part of the Kingdom of Denmark and under Danish sovereignty.

As supportive arguments to the "zero-sum principle," the PCIJ emphasize the Danish de facto engagement in the exploration of Greenland, giving weight to scientific explorations, ${ }^{133}$ and the establishment of Angmagssalik $\left(65^{\circ} 36^{\prime} 42^{\prime \prime} \mathrm{N}\right)$ and Danish legislation for Greenland. ${ }^{134}$ All in all: "[T]he conclusion may be drawn that Denmark through her greater activity in Greenland had thereby acquired prescriptive rights which tended to becloud the Norwegian claim." 135 
Regarding the Norwegian position, the Court highlighted Norway's change of opinion. "On the Norwegian side it was gradually made clear that, in the opinion of the Norwegian Government, the uncolonized part of the East coast of Greenland was terra nullius, and that Denmark's political aspirations could only be met if it involved no sacrifice of Norwegian economic interests." ${ }^{136}$ While Denmark in its oral and factual proceedings kept a steady course, the court seems to have maintained that Norway followed an opportunistic route.

\section{Conclusion: The role of the Inuit and other explanations}

How can we explain the PCIJ decision? Did it follow strictum jus, was it ruled by equity law (ex aequo et bono) or did extra-legal elements, like economy or politics, play a role in the ruling?

In the aftermath of the 1933-court decision several theories has been launched on division of peoples, some civilized, but not all. The "cultivated" nations' division between peoples and nations, paved the way for European lawful annexation of colonies around the world. A rather common Western view deemed natives as objects (slaves or serfs) and not legal subjects nor individuals with legal capacity. ${ }^{137}$ Natives were objects eligible to possession by the group of civilized persons. Like the Homo sapiens $^{138}$ one encountered a similar split between nations, remnants of which are found in the two notions of uncivilized and "civilized peoples,"139 as illustrated by

the 1945 Statutes of the International Court of Justice, Article 38.1 (c). ${ }^{140}$ While the boundaries of civilized nations enjoyed international law protection through the doctrine of "territorial integrity," the homelands of natives, despite the presence of well-organized societies and governing systems, faced the grim destiny of inhabiting terra nullius.

Was the end-result of the 1933-court case political? If the court had justified the Norwegian occupation, would it have imperiled the superpowers' colonial policies ${ }^{141}$ in casu claims of independence by indigenous peoples? The position was that a Norwegian gain at the PCIJ would have represented a threat against the prestigious system of European treaties. If the Norwegian 1931-32 occupation could breakaway East-Greenland from the rest of Greenland, this result could produce a knock-on effect on other territories around the world. Thus, the claimed superior principle of "territorial integrity" would no longer overrule "declarations of independence" or "declaration of annexation."

Alternatively, the realities are even grimmer: A victory for the Norwegian position might have undermined the patronage of the system of European treaties. ${ }^{142}$ Why could national states by "discovery" and annexation - often forced upon native inhabitants by military strength and insensitive feeling for natives as equal human beings, conquer the world under the umbrella of a law accepted by "civilized nations?"

This study reveals that the justifications for the 1933 ruling resulted from a formallogical style of thinking, here named "zero-sum-principle" and excluded any form of 


\section{P. T. Ørebech}

political discretion or legislative reflection. "Making up my opinion by reading this court decision, its basis and keynote, one soon comprehends that the decision - in its entirety - is so to say, pervaded by contract law, while all policy considerations on colonial- and sovereignty considerations are virtually nonexistent." ${ }^{143}$ I adhere to this position.

This article has revealed that sovereignty entitled through occupation requires a "recognized title based on discovery," "a reasonable period by the effective occupation of the region claimed to be discovered" and "the continuous and peaceful display of State authority." 144

The Norse arrival in $986 \mathrm{AD}$ did not observe Inuit settlements in Western Greenland. Later, the natives who arrived were welcomed as the Kings' subjects. The Norse settlers paved the way for Norwegian Kings' sovereignty claims, following Icelandic legal and social arrangements, establishing their own Althing, which the Inuit did not challenge.

A key point is whether the abandonment of the Norse settlements (approx.1450) results in a loss of sovereignty. This does not seem to be the case. The presence of Inuit people during the period of 1450 to 1650 - who at the time were recognized citizens of the Kingdom of Denmark-Norway regardless of their ethnicity, compensated for the Norse disappearance in such a manner as to sustain the sovereignty of this Kingdom over Greenland.

The 1933-court found that the "disappearance of the Nordic colonies did not put an end to the King's pretensions to the sovereignty over Greenland."145 The Kingdom's sovereignty did not suffer from changes in the ethnic population or a provisional downfall of settlements. The Court failed to find that any "massacre" had taken place, or that "the fact of Inuit 'conquest' [was] established." "146 To the contrary, the Court held that the more or less continuous settlements - whether it was Norse or Inuit - qualified.

Despite the fact that the Inuit and Norse settlements were located in WestGreenland only - before the east coast 1894 Scoresbysund settlement - the few scattered settlements on the world's largest island did not undermine the original Norse occupation of the whole of Greenland. The failed Norwegian annexation of 1931-32 resulted from the simple fact that East Greenland was not in any way terra nullius, a status that persisted through the centuries despite the absence of Norse authorities for two centuries in the late Middle Ages.

While these are arguments are supportive of Denmark, the decisive argument, however, is what I call the "zero-sum principle." The extensive Norwegian - and later Dano-Norwegian Kingdom - weakened and successively lost a huge number of territories. When Norway acceded to the Kingdom of Sweden in 1814, the Kingdom of Denmark retained a few non-transferred dependencies. The same conclusion derives from a purely textual interpretation of the 1814 Kiel Treaty Article 4: As explicitly stated, the treaty entitled the transfer of Norway to the Kingdom of Sweden with the exception of Greenland, the Faroe Islands and Iceland. 


\section{NOTES}

1. Den norske regjering [The Norwegian Government], Duplikk angående Den rettslige status for visse Deler av Ostgrønland fremlagt for den faste Domstol for mellemfolkelig rettspleie 14 oktober 1932 [Rejoinder regarding The legal status for Parts of East Greenland for the PCIL] (Oslo: Grøndahl \& Søn, 1933),63.

2. ICJ, Western Sahara, Advisory Opinion, 1.C.J. Reports 1975, p. 12 and 39.

3. Permanent Court of International Justice (PCIJ), Legal status of Eastern Greenland Judgment of April 5th 1933 Series A./B. (1933) No. 53, p. $22 \mathrm{ff}$.

4. Jón Dúason, Grønlands statsretslige stilling $i$ middelalderen [The Greenland Constitutional Law Position in the Middle Ages] (Oslo: Olaf Nordli Forlag, 1928), 153.

5. Supra n.2.

6. See however Henry R. Wagner, "Creation of Rights of Sovereignty through Symbolic Acts," Pacific Historical Review 7, no. 4 (1938): 297-326.

7. See also Arthur S. Keller, Oliver J. Lissitzyn, and Frederick J. Mann, "Reviewed Work: Creation of Rights of Sovereignty through Symbolic Acts, 1400-1800," Harvard Law Review 51, no. 8 (1938): 1475.

8. United Nations. The Island of Palmas Case PCA, II, pp. 829-71 (1928), p. 836.

9. Catherine J. Iorns, "Indigenous Peoples and Self Determination: Challenging State Sovereignty," Case Western Reserve fournal of International Law 24 (1992): 199-348.

10. St.prp. nr. 30 (1924) Om Stortingets samtykke til at regjeringen avslutter en overenskomst med Danmark angående Østgrønland [On the National Assembly Affirmation to the Government's Agreement with Denmark Regarding East-Greenland] of 28 Januar 1924.

11. Norwegian Promemoria of 6. January 1931 Denmark rejects the Norwegian declaration on policing authority in East Greenland (see Danish Verbal Note to Norway of 14 March 1931, referring to a similar note of 9 July 1924 - annexed to the 1924-treaty. National Archive, Box 25 Ministry of Fiskeries, Norway Svalbard- and Polar council (1930-1933) $\mathrm{RA} / \mathrm{S}-1263 / 1 / \mathrm{E} / \mathrm{Ea} / \mathrm{L} 0025$,

12. For a full account, see Jon Skeie, Politikere og diplomater $i$ Grønlandssaken [Politicians and Diplomat's Role in the Greenland Case] (Oslo: Olaf Norli Forlag, 1933).

13. Supra n.1, p. 63.

14. See i.a. Innst. S. XXXXIX (St.prp. nr. 30 - 1924) Innstilling frå den forsterkede og utvidede konstitusjons- og utenrikskomite om Grønlandsspørsmålet, St.prp. nr. 30 (1924) Om Stortingets samtykke til at regjeringen avslutter en overenskomst med Danmark angående Østgrønland (28 januar 1924), Innst. S. LXVI (1923) - Stortingets vedtak av 7. juli 1923 om å innby Danmark til forhandling om Grønlandsspørsmålet «på fritt grunnlag» og St.med. nr. 13 (1932) Angående Grønlandssaken [Regarding the Greenland Case].

15. Supra n.14, p. 7.

16. Op.cit., 23.

17. Op.cit., 23.

18. Knud Berlin, Danmarks rett til Grønland [Denmark's possession to Greenland] (Kjøbenhavn: Nyt Nordisk Forlag - Arnold Busck, 1932), 138.

19. Op.cit., 3: "Det danske uttrykk «suverenitet over hele Grønland som har vært fastholdt gjennem århundrer»"

20. Supra n.1, p. 3.

21. Op.cit., 45.

22. Jon Skeie, Gronlandssaken [The Greenland Case] (Oslo: Olaf Norli Forlag, 1931), 80. Great Britain, Italy and Sweden acknowledged the action that resulted in the USA, France and Japan subsequent support to de facto occupation of areas beyond the settlements.

23. Supra n.1, p. 18. 


\section{P. T. Ørebech}

24. An expedition of priests took place in 1266 when Inuit peoples occurred at a place called Kroksfjordheden, see Dúason, Grønlands statsretslige stilling $i$ middelalderen [The Greenland Constitutional Law Position in the Middle Ages], 80.

25. Supra n.1, p. 5.

26. Anonyms, Norway and East Greenland. A Short Survey (Oslo: Norwegian Publications, 1931), 9.

27. Berlin, Supra n.17.

28. Supra n.1, p. 37.

29. Skeie, Supra n.22, pp. 65-72 - which also was the Fridtjof Nansen position (p. 14).

30. For details, see Frode Fyllingsnes, Undergongen til dei norrøne bygdene på Grønland. Eit forskningshistorisk oversyn [The Downfall of the Norse Settlements in Greenland during the Late Middle Ages] (Oslo: Middelalderforum, 1990), $31 \mathrm{ff.}$

31. Op.cit., 58.

32. Supra n.1, pp. 39-40.

33. Arguing against the Norwegian position of Eastern Greenland as terra nullius, see i.a. Peter Wilhelm Glob, En nordbos gravkors på Grønlands østkyst, Minjar og Menntir. Afmcelisrit $ठ$ Helga Kristjáni Eldjárn (Menningarsjóður, Reykjavík, 1976), 208-19.

34. Iorns, Supra n.9, pp. 199-348, p. 203.

35. Supra n.1, p. $27 \mathrm{ff}$.

36. Supra n.3, p. 22 ff., p. 44.

37. L.c.

38. For details, see Dúason, Supra n.4, p. 76.

39. Op.cit., 79 .

40. L.c.

41. Arnold Ræstad, Supra n.17, p. 83. "På overflaten kan det se ut som det var forskjellen i bedømmelsen av Ihlens erklæring som gjorde utslaget; men i virkeligheten kunde den spesielle bedømmlse av erklæringen som flertallet kommer til ikke ha fått avgjørende virkning, om den ikke var blitt koblet sammen med en særskilt teori om betingelsene for å erverve suverenitet over ingenmannsland."

42. Royal Norwegian Proclamation of July 10th 1931.

43. See i.a. Anton Wilhelm Brøgger, Dommen $i$ Haag [The Hague Judgment] (Oslo: Aschehoug, 1933), 105 - with reference to Manchester Guardian April 7th 1933.

44. W. Paul Gormley, "The Eastern Greenland Case in Historical Perspective," Tulsa Law Review 3 (1966): 93-102.

45. Supra n.3, p. 22 ff., p. 73.

46. Ida Bull, Kampen om Eirik Raudes Land [Fighting for the Land of Eirik the Red] (Oslo: Gyldendal, 1973), 58: «Ihlens erklæring ble et av de avgjørende punkter ... Ihlens erklæring alene var ifølge domstolens oppfatning tilstrekkelig til å berøve Norge retten til å okkupere på Øst-Grønland».

47. Ida Bull, Supra n.45, p. 17 diversify this fault to the entire Norwegian government that - as documented by professor Bull - altogether stood behind the Ihlen declaration.

48. Finn H. Eriksen, Grønlandssaken. Dansk Grøndlandspolitikk og norske reaksjoner 19091933 [The Greenland Case. Danish Greenland Policy and Norwegian responses] (Master thesis, University of Oslo, 2010). "Ihlen-erklæringen ... har ... en kommunikasjonsfeil som kunne ha ført til en annen presisering og tolkning av erklæringen ... Hadde dette blitt oppdaget kunne hele rettssaken i Haag fått et annet utfall."

49. Brøgger, Supra n.42, pp. 117-18.

50. Gormley, Supra n.43, pp. 93-102, at p. 97.

51. Ræstad, Supra n.17, p. 83.

52. Supra n.3, p. 62.

53. Supra n.3, p. 22 ff., p.64. 
54. Charles Cheney Hyde, "The Case Concerning the Legal Status of Eastern Greenland," The American fournal of International Law 27, no. 4 (1933): 732-8.

55. See however, Gormley, Supra n.43, p. 93.

56. Supra n.3, p. 22 ff., p. 69.

57. L.c.

58. Supra n.3, p. 22 ff., p. $72-3$.

59. Supra n.3, p. 22 ff., p. 73.

60. Iorns, Supra n.9, pp. 199-348, p. 230.

61. Heather Pringle, "Death in Norse Greenland," Science 275 (1997): 924-6, subscribes to a late arrival of $1100 \mathrm{AC}$. This is disputed as other sources estimate arrival in approx. 900 AC, see i.a. https://en.wikipedia.org/wiki/Greenlandic_Inuit

62. See i.a. the Marocco occupation of West-Sahara, Supra n.2, p. 12, p.34.

63. A pre-historical customary practice that developed in "fits and starts," see Michael P. Sharf, Customary International Law in Times of Fundamental Change. Recognizing Grotian Moments, 9 (Cambridge University Press, Cambrigde. 2013): "This book does not ... constitute uncritical advocacy of a new paradigm that supports assertions of speedy formation of customary international law that are not backed up by state practice."

64. Dúason, Supra n.4, p. 79.

65. Op.cit., 80-1.

66. Supra n.1, p. 63

67. https://no.wikipedia.org/wiki/Ittoqqortoormiit (visited 11.December 2015).

68. Supra n.1, p. 47.

69. Supra n.1, p. 63.

70. Island of Palmas Case Supra n.8, pp. 829-71 (1928), at p. 870.

71. Island of Palmas Case Supra n.8, pp. 829-71 (1928), at p. 870 .

72. Op.cit., 846.

73. Supra n.3, p. 22 ff., p. 48.

74. Supra n.3, p. 28.

75. Op.cit., 46.

76. ICJ, Western Sahara, Advisory Opinion, 1.C.J. Reports 1975, p. 12, p. 39.

77. Laureen Benton and Benjamin Straumann, "Acquiring Empire by Law: From Roman Doctrine to Early Modern European Practice," Law and History Review 28, no. 1 (2010): 38.

78. James Simsarian, "The Acquisition of Legal Title to Terra Nullius," Political Science Quarterly 53, no. 1 (1938): 111-28.

79. Oscar Svarlien, The Eastern Greenland case in historical perspective (University of Florida Monographs: Social Sciences, No. 21., Gainesville: University of Florida Press, 1964), 73.

80. Simsarian, Supra n.39.

81. Supra n.3, p. 22 ff., p. 47.

82. Supra n.3, p. 22 ff., p. 47.

83. Supra n.8, p. 846.

84. Supra n.8, p. 846.

85. Supra n.8, p. 857.

86. Repertory of Practice of United Nations Organs Supplement No. 7 (Revised advance version, to be issued in volume V of Supplement No. 6 (forthcoming) of the Repertory of Practice of United Nations Organs) Volume V ARTICLE 76 (UN) para 28, p. 9.

87. Declaration of Independence, in effect from 1st October 1994, see UN/A/49/L.51, 7 December 1994 p. 1.

88. UN/S/PV.3455, 10 November 1994 p. 2. The UN Trusteeship Council suspended operation on 1 November 1994, with the independence of Palau, the last remaining United Nations trust territories. 


\section{P. T. Ørebech}

89. James Crawford, The International Law Commission's Articles on State Responsibility: Introduction, Text and Commentaries (Cambridge University Press, Cambridge 2002).

90. Restatement (third) of the Foreign Relations Law of the United States $₫ 201 \& \llbracket 402$ (1987).

91. James Crawford, The Creation of States in International Law, vol. 48, (Oxford University Press, Oxford 1979), 36.

92. Diane F. Orentlicher, "Separation Anxiety: International Responses to Ethno-Separatist Claims," The Yale fournal of International Law 23 (1998): 1, at note 85.

93. John Crawford, Brownlie's, Principles of Public International Law, 8th ed. (Oxford University Press, Oxford 2012), 128.

94. Fridtjof Nansen. Eskimoliv [Inuit-life] (H. Aschehoug \& co. Forlag, Kristiania, 1891), 94.

95. International law has gradually developed inter partes backed by Church decrees, i.a. 1179 Third Lateran Council that condemned piracy against Christians, Spain-Portugal partition of the Atlantic Ocean by Pope Confirmation of 1493 \& 1506; and a number of bilateral agreements, i.a. Norway-Russia Peace treaty and boundary agreement of June 3rd 1326.

96. This is the position of Dúason Supra n.4, p. 79. See also p. 92.

97. Laureen Benton and Benjamin Straumann, "Acquiring Empire by Law: From Roman Doctrine to Early Modern European Practice," Law and History Review 28, no. 1 (2010): $11 \mathrm{ff}$. and 38.

98. Island of Palmas Case Supra n.8, pp. 829-71 (1928), p. 855.

99. Supra n.8, p. 867.

100. Supra n. 8 , p. 868 .

101. Op.cit.

102. Island of Palmas Case Supra n.8, pp. 829-71 (1928), p. 870.

103. Op.cit., 840.

104. Supra n.8, p. 839.

105. Island of Palmas Case Supra n.8, pp. 829-71 (1928), p. 846.

106. Op.cit., 846.

107. Supra n.3, p. 22 ff., p. 35.

108. Supra n.3, p. 22 ff., p. 27.

109. Supra n.1, p. 28.

110. Supra n.3, p. 22 ff., p. 27.

111. Oscar Svarlien, Supra n.78.

112. Supra n.3, p. 22 ff., p. 27.

113. A part of our forefathers Kingdom of Norway and its devoted subjects.

114. Supra n.1, p. 28.

115. Knud Berlin, Supra n.17, p. 129: «Rather few knowledgeable Icelandic people would possibly support his position».

116. Dúason, Supra n.4, pp. 139-41.

117. Supra n.1, pp. 31-2 «From this period on the Eskimo was the sole masters of the land».

118. As interpreted in Repertory and its Supplements Nos. 1, 2 and 3, III.

119. Supra n.3, p. 22 ff., p. 64.

120. Island of Palmas Case Supra n.8, pp. 829-71 (1928).

121. Island of Palmas Case Supra n.8, pp. 829-71 (1928).

122. Op.cit., 857.

123. Supra n.3, p. 22 ff., p. 27.

124. L.c.

125. Supra n.3, p. 28.

126. L.c.

127. L.c. 
128. Supra n.3, p. 64.

129. Op.cit., 65.

130. Op.cit., 66.

131. Op.cit., 27.

132. Op.cit., 68.

133. Op.cit. see i.a. p. 40.

134. Op.cit., 31-4, 39-41 etc.

135. Oscar Svarlien, Supra n.78, p. III.

136. Op.cit., 38.

137. Francisco de Vitoria was a "lonely swallow" who objected to the common understanding that "pagans have no right of ownership; therefore, war against them is always lawful." See Alan C. Macdiarmid, "Francisco de Vitoria," New Blackfriars 9 (1928): 495-504.

138. Homo Sapiens Sapiens (modern man - since approximately 90,000 years ago).

139. Robert Williams, The American Indian in Western Legal Thought: The Discourses of Conquest (Alan C. Macdiarmid 1990) Portray the Distinction's Implication.

140. The text was identical under the Permanent Court of International Justice (1920) Article 38(3).

141. Brøgger, Supra n.42, p. 106. ("Norges aksjon var farlig for stormaktenes kolonipolitikk").

142. Op.cit., 106; “ . . europeiske traktaters ukrenkelighet."

143. Brøgger, Supra n.42, p. 106.

144. Supra n.8, p. 846.

145. Supra n.3, p. 27.

146. Op.cit., 47. 